\title{
The Cultivation of College Students' Critical Thinking Ability Based on Task-based Cooperative Writing
}

\author{
Xiaoling Liu \\ College of Foreign Languages, Hunan University, Changsha, P.R. China \\ Ting Yao \\ The Third Middle School, You County, Zhuzhou, Hunan, P.R. China
}

\begin{abstract}
This study attempts to explore the effectiveness of task-based cooperative writing instruction on critical thinking and English writing development. To address the issues, an experiment is carried out between two university classes, who received task-based cooperative writing and traditional non-source based writing respectively. Based on the analysis, the major findings are obtained as follows. Firstly, task-based cooperative writing could effectively cultivate college students' critical thin king abilities in general and students' critical thinking affective disposition and cognitive skill to a significant degree in particular; Secondly, as for the 7 critical thinking sub-dispositions, the analyticity is improved to a significant level while CT-confidence, inquisitiveness, truth-seeking, maturity, open-mindedness and systematicity are not significantly enhanced. And as for the 6 critical thinking sub-skills, interpretation, explanation, inference, and analysis are all developed to a significant extent while self-regulation failed to reach the significant level; Finally, students' writing proficiency is also promoted. College students' critical thinking ability is positively and significantly correlated with their writing proficiency. Among the critical thinking sub-dispositions, there exists a positive correlation between students' writing quality and truth-seeking as well as maturity. And the correlations between the writing quality and all the critical thinking sub-skills are positive and significant.
\end{abstract}

Index Terms — critical thinking ability, task-based cooperative writing, writing quality

\section{INTRODUCTION}

Cultivation of critical thinking (hereafter, CT) ability has been the central goal of modern education, especially for higher education and it has been infiltrated into the interdisciplinary teaching as well. In recent years, the domestic scholars pay more attention to CT and its exploration and have realized the significance and urgency of the CT in higher education. However, the current situation of $\mathrm{CT}$ absence in foreign language learners is evidential.

In the context of Chinese education, many scholars have done studies ranging from theoretical foundation to empirical researches of exploring how to improve students' CT ability in English teaching which involves writing to a great extent. Some studies attempt to assess students' current situation in CT (Wen, 2006). And Wen Qiufang (2006) also mainly focuses on English major student's CT ability and its assessment tool of establishment and evaluation validity as well. And some do researches to explore the strategies and methods of cultivating students' CT ability (Han, 2009; Ling, 2014; Yu, 2014). Their emphasis is a little different that some put the writing as an assessment tool of CT, while others consider CT cultivation as a method to improve writing proficiency. In general, they have made tremendous achievements in CT teaching model construction and put forward many strategies of developing students' CT in English writing teaching. However, no research explored how to foster college English students' CT abilities through task-based cooperative writing.

Therefore, in the integrated college English teaching, teachers have a major responsibility to provide various tasks to develop students' CT ability. Reading and writing are closely connected, and the process of writing can stimulate the application of CT skills, thus various tasks set in the process of writing like the task-based cooperative writing may improve students' CT ability and writing proficiency to some extent. So, this study attempts to explore whether the task-based cooperative writing will be beneficial to students' CT abilities.

\section{LITERATURE REVIEW}

\section{A. Definition of Critical Thinking}

$\mathrm{CT}$ is of practical importance and has theoretical interests in second language teaching. In recent years, it has become 'a buzzword' in the educational circles (Fisher, 2011, P.1), especially in domestic foreign language teaching.

John Dewey defined CT as "reflective thought", which means the active, persistent, and careful consideration of a belief or supposed form of knowledge in the light of the grounds that support it and the further conclusions to which it 
tends (Dewey, 1933).

Facione et al. (1990), who dedicated to the Delphi Project, put forward a new and comprehensive definition of CT. In this report, CT is defined as: "purposeful, self-regulatory judgment which results in interpretation, analysis, evaluation and inference, as well as explanation of the evidential conceptual methodological, criteriological or contextual considerations upon which that judgment is based" (Facione, 1990, P. 2). According to the Delphi Report, CT involves both critical thinking disposition (hereafter, CTD) and critical thinking skill (hereafter, CTS). As for the affective dispositions, it can be divided into seven sub-scales: analyticity, self-confidence, inquisitiveness, maturity, open-mindedness, systemacity and truth-seeking. As for the cognitive skills, it is composed of six sub-scales: interpretation, analysis, evaluation, inference, explanation, and self-regulation, with analysis, evaluation and inference as the key three skills. Following the scholars, the definition from the Delphi report that the CT ability was constructed of skills and dispositions is ideal for this study.

\section{B. Assessment of Critical Thinking Ability}

Since CT becomes a central focus, numerous CT assessment tools are also developed in order to measure students' CT ability. The most popularized assessment tools are the California Critical Thinking Disposition Inventory (hereafter, CCTDI; Facione \& Facione, 1992) and the California Critical Thinking Skills Test (hereafter, CCTST, Facione, 1990), which emerged from the Delphi report on CT, Watson-Glaser Critical Thinking Appraisal (Watson \& Glaser, 1980), Cornell Critical Thinking Test, Level Z (Ennis et al., 1985), and the Qualitative Florida Scale for Critical Thinking Skills (hereafter, UF/QCTS; Tian, 2012) and so on. Among these measuring instruments, the CCTDI is to test students' CTD and the others are to measure students' CTS objectively or subjectively.

After literal translation, the origin version of CCTDI is not expected to mirror the Chinese students' CT disposition. So, the Chinese version of CCTDI (hereafter, CTDI-CV) is developed under the leadership of Peng Meici (2004). What's more, as for the assessment of CTS, the UF/QCTS has been adopted in many researches (Tian, 2012; Huang, 2013), whose scoring rubric and rating scale are established by the researchers around the constructs of explanation, inference, evaluation, analysis, interpretation and self-regulation (Facione, 1990). It can provide specific standards to assess a certain kind of CT skills based on writing.

Thus, in this study, CTDI-CV can be used to evaluate the general level of students' CTD and the standard of UF/QCTS can be employed to evaluate the specific sub-skills of students' CT in their writing. And these tests have been chosen for the subsequent study mainly for three reasons except for their validity and reliability: first, they are primarily consistent with and responsive to the Delphi Exercise on CT; second, they offer precise measurement to assess a specific cognitive skill or disposition essential for college English students applying to their writing; third, there are substantial studies base using these tests, which are helpful for the comparison purpose.

\section{Task-based Writing}

Task-based approach was an approach on the basis of the application of task as the core element in language teaching or instruction. The task-based writing, with emphasis on depth of writing content rather than breadth, is exactly the reflection of CT. Wang Dongping (2005) has examined the effectiveness of the task-based writing in the college English writing teaching. In her research, the structures, main phrases and flow chart of a task-based writing approach were explained and such approach was prior to the writing product approach. Therefore, the task-based writing is a promising method in EFL writing instruction.

\section{Definition and Component of a Task}

With regards to the quality of the writing production, the task-based approach mainly captures students' writing as a process, in which various tasks conducive to students' writing conception could be designed.

According to Jane Willis (1996), task is a goal-oriented activity. And tasks are considered as the central component of a three-part framework: Pre-task, task cycle and language focus. In the pre-task stage, extensive exposure could be provided for learners to recall the prior information or knowledge. And the topic and specific tasks should be clarified to raise learners' acquisition awareness and make them fully prepared for the task.

Ellis (2003) describes that task is a workplan that requires students to process language, with emphasis on evaluating whether appropriate contents have been delivered by obtaining certain outcomes from the tasks. And he put forward four standards for defining task:1) mainly focus on meaning; 2) have a certain gap; 3) learners fulfill the activities by using linguistic materials and nonverbal sources; 4) have exact outcomes in addition to language use.

For this study, it is difficult to design writing tasks strictly within Ellis's standards of task. And Appel \& Lantolf (1994) demonstrates that the fulfillment of a task mainly depends on the interaction between learner and task rather than on the inherent nature of the task itself. Therefore, the task in this study is an activity that mainly focuses on meaning and the interaction forms to inspire students to produce high accuracy and logic composition. And the adoption of task-based cooperative writing in the present study mainly follows Willis's framework of task.

\section{E. Types of Writing Task}

The writing as one of the basic language skills is closely connected with reading, listening and speaking skills. Thus, the writing process is not confined to a certain task pattern and it enables different interdependent task types in 
operation. For instance, Zhang Xinling \& Zhou Yan (2016) investigated the influence of task type involving the impromptu, reading-to-write and reading-listening-writing on different levels of Chinese EFL learners' English writing process. Xu Hao \& Gao Caifeng (2007) explored the effectiveness of reading-to-write teaching mode on students' writing ability and writing thoughts and reading ability. Delaney (2008) investigated the influence of the reading-to-write construct. Wang Wenqiu \& Mou Fanghua (2013) explored that the reading-writing integration teaching mode is effective in bettering students' reading and writing ability.

And the group task with emphasis on mutual discussion could help students gather different ideas and get more familiarized with the writing topic. Li Shaofang (2009) claimed that the cooperative learning could be involved in the integration of task-based writing method with reading or speaking, which could make use of intensive intelligence to implement the writing task.

In summary, various tasks could be adopted in combination in the writing process. Therefore, task-based cooperative writing in this study could be designed in an interactive way in order to strengthen students' CT ability.

\section{F. Critical Thinking and Task-based Writing}

The CT ability in foreign language learning is usually demonstrated in the output activities such as speaking or writing and it seems that it is more easily reflected by cogitative writing production rather than impromptu spoken language. Researchers (Sun, Liang \& Wen, et al., 2011) have claimed that the integral link between writing and CT should be taken seriously. Meanwhile, the studies on English writing and CT have gradually increased. Some look into the relationship between writing and CT cultivation. For example, Tusil (1999) studied the various types of courses and differing teaching methods on students' CT, which found that nine courses involving writing courses and foreign language courses present a significant positive correlation with CT. And his further case study proved that the writing and rewriting, classroom discussion play vital roles in developing students' CT skills. Zhang Xinling (2009) suggested that an interface between CT and reading-to-writing instruction could produce desirable results in English writing classroom.

Ma Rong \& Qin Xiaoqing (2016) implied that the CTD for English majors was holistically positive, in which 4 dimensions including the open-mindedness, analyticity, inquisitiveness, maturity show positive traits, while the other 3 dimensions involving the truth seeking, systematicity and self-confidence show negative traits. And the CTD was testified to be irrelevant to the score of academic reading and academic writing. However, in their research, the relationship between CT sub-dispositions and reading or writing is not investigated.

Some studies mainly concentrate on the cultivation of CT in English writing. Han Shaojie \& Yi Yan (2009) illustrated the importance of CT cultivation in English major students' writing teaching and put forward some efficacious strategies to foster CT ability in writing course. Besides, Li Wenting (2012) proposed to teach writing with the help of networking platform and apply debating into writing teaching thus to develop students' CT ability.

According to the increasing gap between language skills and CT skills development, Yu Jiying (2014) yielded a tentative framework of an integrating teaching approach to English writing and CT skills development which entails integrated teaching objectives, teaching materials and teaching methods. But he just explored from the theoretical foundations.

Besides, there are also more empirical studies concerning how to improve CT ability in writing instruction. Tian Dan (2012) suggested that foreign language learners' CT abilities in inference, analysis, evaluation etc. have got greatly improved while no obvious effect was produced on self-regulation skill by conducting a three-round action.

As mentioned in the literature above, researches have pinpointed the integral link between the overall CT and English writing. However, the correlations between CT sub-skills or CT sub-dispositions and English writing quality were scarcely investigated except in Ma \& Qin's research. And they didn't consider both CT sub-dispositions and sub-skills from both objective and subjective perspective. Therefore, it is imperative to conduct a study to explore the effect of task-based cooperative writing on critical thinking cultivation.

\section{G. Cooperative Writing and Cultivation of Critical Thinking}

Writing is a significant feature of teaching and learning in EFL settings and the classroom structures in higher education has increasingly shifted from individual work to group or team work. Thus, a wide variety collaborative work could be applied in EFL writing classroom to develop learners' self-expressing and writing skills. According to Lowry et al. (2004), collaborative writing was an iterative process that enables a team to participate in negotiating, communicating and coordinating with a particular shared target in the process of creating written output. And its' potential scope not merely lies in the basic art of joint composition but involves the pre-task and post-task activities, team formation and planning. Furthermore, it includes the likelihood of various writing strategies, activities, team roles and work modes. Following Lowry et al.'s understanding, the task-based cooperative writing in this study mainly refers to the collaborative form for task-based writing.

The value and potential pedagogical benefits of cooperative writing has been examined and discovered from various perspectives. For instance, Hodges (2002) stated that collaborative writing could enhance students' initiative, creativity and critical thinking. Wang et al. (2009) investigated critical thinking and knowledge construction in an interactive learning environment. The findings showed that writing reflections had potential to promote critical thinking but, not all students thought critically. Although their research was not thoroughly based on the cooperative writing, they designed 
interaction forms such as class discussions that was consistent to this study to some extent.

Ji Shourong (2008) put forward that the cooperative writing based on the metacognitive strategy was an effective way to enhance students' critical thinking ability. However, his research just explored the theoretical framework of cooperative writing to enhance CT.

Karama et al. (2012) suggested collaborative learning providing a suitable context for students' critical thinking dispositions could be applied in the education system. However, their research mainly focused on critical thinking dispositions while the critical thinking skills were neglected.

To sum up, responding to these researches, the cooperative writing could potentially contribute to enhancing critical thinking ability and there is persuasive evidence that cooperative team study achieves at higher levels of thought and secure information longer than students studying silently as individuals. Therefore, the task-based cooperative writing will be beneficial to students' CT ability.

\section{RESEARCh DESIGN}

\section{A. Research Questions}

To investigate the effect of cooperative task-based writing on critical thinking ability, the study mainly addressed the following research questions:

1. Will the task-based cooperative writing cultivate college students' critical thinking ability?

2. Are there any improvement differences in terms of sub-critical thinking skills and sub-critical thinking dispositions? If so, are they significant?

3. Is there any correlation between students' writing quality and their overall critical thinking ability as well as critical thinking sub-categories?

\section{B. Participants}

Fifty second-year undergraduate non-English majors from two intact classes $(n=50)$ are chosen: Chemistry (class 1$)$ and Mechanics majors (class 2) at Hunan Institute of Science and Technology. The average English achievement scores of two classes achieved in previous semester were approximately the same, and all subjects' writing quality and CT consisting of CTD and CTS had no significant discrepancy at the beginning of the experiment. Meanwhile, none of them have received formal CT training before according to the questionnaire of CTDI-CV. Class1 (Chemistry majors) is chosen randomly as the experimental group to complete the task-based cooperative writing and class2 (Mechanics majors) as the control group to complete the topic writing task.

\section{Instruments}

Instruments used in this study consisted of CTDI-CV, UF/QCTS and the readability analyzer 1.0 and the SPSS 22.0. The CTDI-CV assessing students' CT dispositions were used in both pretest and posttest. And instrument adopted in pretest and posttest to measure subjects' CT skills in writing was based on UF/QCTS. And assessing of writing was based on CET-6.

\section{Materials}

The study was conducted in the integrated college English class. The coursebook used in college English teaching was New Horizon College English (1-4) published by Foreign Language Teaching and Research Press. The teaching and testing materials which were used in this study consisted of 1) the New Horizon College English Book 3: Reading and Writing (Third Edition); 2) three reading passages cited from the newspaper; 3) the questionnaire of CTDI-CV in pretest and posttest;

Three reading passages for their writing tasks were related with the reading topics in unit 3 and Unit 4 and Unit 5 of New Horizon College English book 3. Each passage would contain about 400 words. The Readability_Analyzer_1.0 would be used to ensure the difficulty level of the reading texts. The difficult level of the reading materials for this study was appropriate for the subjects.

TABLE I

READABILITy Statistics Of ThreE READING TEXTS AND A TEXT ROM BOOK

\begin{tabular}{|l|l|l|l|l|}
\hline Text & Text1 & Text2 & Text3 & S-Text \\
\hline Reading Ease & 1.00 & 1.00 & 1.00 & 1.00 \\
\hline Text Difficulty & 99.00 & 99.00 & 99.00 & 99.00 \\
\hline Grade Level & 1.00 & 1.00 & 1.00 & 1.00 \\
\hline Sentences & 1 & 1 & 1 & 1 \\
\hline ASL & 1.00 & 1.00 & 1.00 & 1.00 \\
\hline AWL & 1.00 & 1.00 & 1.00 & 1.00 \\
\hline Tokens & 388 & 386 & 396 & 350 \\
\hline Word Types & 205 & 186 & 222 & 191 \\
\hline Lemma Types & 191 & 166 & 202 & 176 \\
\hline Lemma/Word Ratio & 0.9317 & 0.8925 & 0.9099 & 0.9215 \\
\hline Word TTR & 0.5284 & 0.4819 & 0.5606 & 0.5457 \\
\hline Word STTR & 0.5284 & 0.4819 & 0.5606 & 0.5457 \\
\hline
\end{tabular}


As for testing materials, the CTDI-CV (Peng et al., 2004) investigating students' CTD was distributed to subjects in both pretest and posttest. The CTDI-CV is a 6-Likert scaled questionnaire with seventy testing items demonstrating seven scales of CTD, and each scale includes ten items. 20 minutes are needed to complete it. Generally, there are eight kinds of scores which are respectively the total score and seven sub-scales score.

The scoring of the writing test was finished by two teachers from Hunan Institute of Science and Technology. The grading standard in pretest and posttest would mainly depend on two parts, one is the evaluation rubrics of CET-6, primarily concentrating on accuracy of grammar, rationality of structure and expression, and the other is the grading criteria of the Qualitative Florida Scale for CT Skills (UF/QCTS) test. And the full score of each sub-scale is marked with 5 and the lowest score will be 0 and the total points are 30 .

\section{E. Procedures}

The experiment started at the beginning fall semester in 2016, which totally lasted for 8 weeks. In the pretest, all subjects were required to finish the questionnaire independently in 20 minutes which is to investigate students' CTD. And students were asked to finish an essay My Views on Club Activities within 30 minutes in class which is to investigate students' CTS and their current writing proficiency.

In the 6 weeks' experiment, the study designed task-based cooperative writing in the experimental class and topic writing in the control class. And the setting and course arrangement between the experimental and the control group are synchronous. For the control group, the teacher directly gives students the writing topic and requires them finish the writing in class within 30 minutes. Meanwhile, Class 1 was implemented the task-based cooperative writing following the Willis' framework of task-based writing. It is divided into five steps in this study: reading, group discussing, verbal report and final writing and evaluation.

TABLE II.

TEACHING PROCEDURES FOR PREPARING INGREDIENTS

\begin{tabular}{|c|c|}
\hline Time allocation & Teaching plan \\
\hline \multirow{3}{*}{ Lesson 1 } & Reading (3 min) \\
\cline { 2 - 2 } & Group discussion (6 min) \\
\cline { 2 - 2 } & Verbal report (6 min) \\
\cline { 2 - 2 } & Final writing \& collecting (30 min) \\
\hline After class & Grading \\
\hline Lesson 2 & Evaluation \\
\hline
\end{tabular}

After the intervention, the subjects were required to write an essay cited from CET-6 in November, 2016. Meanwhile, the CTDI-CV was also distributed to them. All subjects have taken the tests and their scales of CTDI-CV and writings were collected altogether at the same time.

\section{F. Data Collection and Data Analysis}

All the 50 subjects have attended the pretest and posttest. The results of the CTDI-CV and writing tests in pretest and posttest were all collected to measure subjects' CT abilities and writing quality. Data from the questionnaires and writings in both pretest and posttest were collected and demonstrated. While using SPSS 22.0, the Descriptive Statistics, Independent Samples T-test, Paired Samples T-Test, Pearson Correlation Analysis would be fully processed.

\section{RESULT AND DISCUSSION}

\section{A. Improvement of Students' Critical Thinking Ability}

In order to discuss whether the task-based cooperative writing is beneficial to the cultivation of college English students'CT ability, the analysis started with demonstrating the general level of students' CTD and CTS in pretest and posttest. And then the differences of subjects' CT as a whole could be reflected through the inner group comparison based on the paired samples t- test.

1. Critical Thinking Disposition

In order to investigate subjects' development of CTD, both independent samples t-test and Paired samples t- Test were presented as shown in table 3 , and table 4.

TABLE III

INDEPENDENT SAMPLES TEST OF Two CLASSES' CTD In PRETEST AND POSTTEST

\begin{tabular}{|c|c|c|c|c|c|c|c|c|c|}
\hline \multicolumn{7}{|c|}{ Group Statistics } & \multicolumn{3}{|c|}{ Independent Samples Test } \\
\hline & Class & $\mathrm{N}$ & Mean & $\begin{array}{c}\text { Std. } \\
\text { Deviation }\end{array}$ & Min & Max & $\mathrm{F}$ & $\mathrm{t}$ & $\begin{array}{l}\text { Sig. } \\
\text { (2-tailed) }\end{array}$ \\
\hline Pretest & $\begin{array}{l}1 \\
2\end{array}$ & $\begin{array}{l}25 \\
25\end{array}$ & $\begin{array}{l}229.040 \\
232.200\end{array}$ & $\begin{array}{l}24.1824 \\
26.9351\end{array}$ & $\begin{array}{l}171 \\
173\end{array}$ & $\begin{array}{l}274 \\
278\end{array}$ & .290 & $\begin{array}{l}-.436 \\
-.436\end{array}$ & $\begin{array}{l}.664 \\
.664\end{array}$ \\
\hline Posttest & $\begin{array}{l}1 \\
2\end{array}$ & $\begin{array}{l}25 \\
25\end{array}$ & $\begin{array}{l}241.520 \\
236.360\end{array}$ & $\begin{array}{l}26.3788 \\
24.9598\end{array}$ & $\begin{array}{l}187 \\
180\end{array}$ & $\begin{array}{l}304 \\
294\end{array}$ & .017 & $\begin{array}{l}.710 \\
.710\end{array}$ & $\begin{array}{l}.481 \\
.481\end{array}$ \\
\hline
\end{tabular}


The $\mathrm{P}$ values are 0.664 and 0.481 respectively, much higher than 0.05 , proving that no significant difference exists in their CTD. However, the experimental group $(M=229.04)$ scores lower than the control group $(M=232.20)$ in pretest, although not significantly lower.

Then, after implementing different writing tasks, the mean score of experiment group (mean=241.52) is noticeably higher than that of control group in posttest (mean=229.04). Although their scores were both increased, the performance of experiment class in CTDI-CV varied more comparing to the control class. So, it can be discovered that the whole level of students' CTD in experiment class has been improved to some extent after embedding the task-based cooperative writing.

And after the intervention, the inner group comparison of students' CTD on the whole level should also be conducted to measure the differences of the two classes' CTD.

TABLE IV

PAIRED SAMPLes Test Of Two Classes' CTD In PRETESt AND POSTTEST

\begin{tabular}{|c|c|c|c|c|c|c|c|c|c|}
\hline \multicolumn{6}{|c|}{ Paired Samples Statistics } & \multicolumn{4}{|c|}{ Paired Samples Test } \\
\hline & & \multirow[b]{2}{*}{ Mean } & \multirow[b]{2}{*}{$\mathrm{N}$} & \multirow{2}{*}{$\begin{array}{c}\text { Std. } \\
\text { Deviation }\end{array}$} & \multirow{2}{*}{$\begin{array}{l}\text { Std. Error } \\
\text { Mean }\end{array}$} & \multicolumn{2}{|c|}{$\begin{array}{l}95 \% \text { Confidence } \\
\text { Interval of the } \\
\text { Difference }\end{array}$} & \multirow[b]{2}{*}{$\mathrm{t}$} & \multirow[b]{2}{*}{ Sig.(2-tailed) } \\
\hline & & & & & & Lower & Upper & & \\
\hline Class 2 & $\begin{array}{l}\text { Pre_2 } \\
\text { Post_2 }\end{array}$ & $\begin{array}{l}232.20 \\
236.36\end{array}$ & $\begin{array}{l}25 \\
25\end{array}$ & $\begin{array}{l}26.935 \\
24.960\end{array}$ & $\begin{array}{l}5.387 \\
4.992\end{array}$ & -14.081 & 5.761 & -.865 & .395 \\
\hline Class 1 & $\begin{array}{l}\text { Pre_1 } \\
\text { Post_1 }\end{array}$ & $\begin{array}{l}229.04 \\
241.52\end{array}$ & $\begin{array}{l}25 \\
25\end{array}$ & $\begin{array}{l}24.182 \\
25.894\end{array}$ & $\begin{array}{l}4.836 \\
5.179\end{array}$ & -24.582 & -.378 & -2.128 & .044 \\
\hline
\end{tabular}

As it can be seen that the $\mathrm{P}$ value is $0.395(\mathrm{P}>0.05)$, which implicates that no significant discrepancy exists on the control group's overall CTD in pretest and posttest. Meanwhile, in the experiment class, it can be seen that the P value is $0.044(\mathrm{p}<0.05)$, which points out that the differences of experiment group's overall CTD reach the significant level after the intervention.

What's more, the frequency analysis of two classes' CTD in pretest and posttest is also presented to demonstrate their improvements as the figure1.

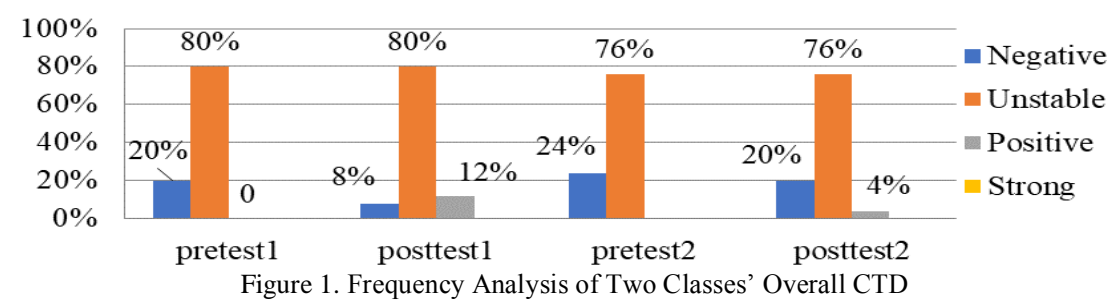

As described in figure $1,80 \%$ of subjects' overall CTD tends to be unstable and $20 \%$ of the students show negative dispositions of $\mathrm{CT}$ in the pretest of the experiment group. However, after the instruction of task-based cooperative writing, only $8 \%$ of the students have negative CTD and $12 \%$ of the students are considered as positive in the CTD. In general, the number of subjects with a negative mind toward CT has entirely decreased by $12 \%$. However, for the control group in posttest, there are still $20 \%$ of the students show negative disposition and only one student is positive in the overall CTD. It is noteworthy that neither group of students achieved the score of 350 that is considered the threshold for strong disposition for critical thinking. According to Facione et al. (1998) stated that the CT dispositions were positively correlated with the conventional personality trait and the consistent internal motivation to think. And Han Shaojie (2009) believed that the CT dispositions need to be cultivated in the long process of thinking activities. Therefore, it is difficult for learners to improve their CT dispositions in such a short training especially when learners' initial CT dispositions were relative unstable and weak.

Although the CTD of both groups is in the unstable stage, the difference in the critical thinking disposition is found statistically significant in favor of the group that implements the task-based cooperative writing. Therefore, it can be concluded that the task-based cooperative writing facilitates students' CTD.

2. Critical Thinking Skill

Despite exploring students' CTD, CTS is also integral to measuring students' CT abilities. First, the overall situation of two groups' CTS in the pretest and posttest is demonstrated based on the independent samples test through table 5. 
TABLE V.

INDEPENDENT SAMPLES TEST OF TwO CLASSES' CTS In PRETEST AND PostTEST

\begin{tabular}{c|c|c|c|c|c|c|c|c|c}
\hline \multicolumn{1}{c}{ Group Statistics } & \multicolumn{4}{c}{ Independent Samples Test } \\
\hline \multirow{2}{*}{ Pretest } & Class & $\mathrm{N}$ & Mean & Std. Deviation & Max & Min & F & t & Sig. (2-tailed) \\
& 1 & 25 & 9.380 & 2.5136 & 14 & 6 & \multirow{2}{*}{1.039} & -.728 & .470 \\
& 2 & 25 & 9.980 & 3.2675 & 14 & 6.5 & & -.728 & .471 \\
\hline Posttest & 1 & 25 & 16.620 & 4.5809 & 24 & 7.5 & \multirow{2}{*}{1.532} & 3.888 & .000 \\
& 2 & 25 & 12.060 & 3.6609 & 18 & 6.5 & & 3.888 & .000 \\
\hline
\end{tabular}

As is shown in table 5, the mean scores and the maximum score show that both groups' CTS has been enhanced to some extent. The $\mathrm{P}$ value in pretest and posttest is respectively $0.470(\mathrm{P}>0.05)$ and $0.000(\mathrm{P}<0.05)$, showing that subjects' CTS in pretest has no significant difference but after the experiment, subjects' CTS has reached to a significant degree.

Furthermore, the inner group comparison for students' overall CTS is also conducted based on the paired samples test.

TABLE VI.

Paired SAmples Test Of WO Classes’ CTS In PRetest And PostTest

\begin{tabular}{|c|c|c|c|c|c|c|c|c|c|}
\hline \multicolumn{6}{|c|}{ Paired Samples Statistics } & \multicolumn{4}{|c|}{ Paired Samples Test } \\
\hline & & \multirow[b]{2}{*}{ Mean } & \multirow[b]{2}{*}{$\mathrm{N}$} & \multirow[b]{2}{*}{ Std. Deviation } & \multirow{2}{*}{$\begin{array}{l}\text { Std. Error } \\
\text { Mean }\end{array}$} & \multicolumn{2}{|c|}{$\begin{array}{l}\text { 95\% Confidence Interval } \\
\text { of the Difference }\end{array}$} & \multirow[b]{2}{*}{$\mathrm{t}$} & \multirow[b]{2}{*}{ Sig.(2-tailed) } \\
\hline & & & & & & Lower & Upper & & \\
\hline Class 2 & $\begin{array}{l}\text { Pre_2 } \\
\text { Post_2 }\end{array}$ & $\begin{array}{c}9.980 \\
12.060\end{array}$ & $\begin{array}{l}25 \\
25\end{array}$ & $\begin{array}{l}3.2675 \\
3.6609\end{array}$ & $\begin{array}{l}.6535 \\
.7322\end{array}$ & -3.9064 & -.2536 & -2.351 & .027 \\
\hline Class 1 & $\begin{array}{c}\text { Pre_1 } \\
\text { Post_1 }\end{array}$ & $\begin{array}{c}9.380 \\
16.620\end{array}$ & $\begin{array}{l}25 \\
25\end{array}$ & $\begin{array}{l}2.5136 \\
4.5809\end{array}$ & $\begin{array}{l}.5027 \\
.9162\end{array}$ & -9.3432 & -5.1368 & -7.105 & .000 \\
\hline
\end{tabular}

As is shown in table 6, the $\mathrm{P}$ values of 0.027 and $0.000(\mathrm{P}<0.05)$ suggest a statistically significant difference after the experiment. Although both two groups have made a progress in CTS, the experiment group' CTS is enhanced into a more significant level. Because its' mean score has increased from 9.38 to 16.62. Therefore, students' CT skills in experiment group have been extremely strengthened.

In conclusion, it can be noted that the channel of task-based cooperative writing produced significantly better achievement on cultivating students' CTD and CTS from the whole picture. The results could demonstrate the theoretical framework in which cooperative writing task could be an effective way for CT cultivation and it was an effective way to enhance students' critical thinking ability (Yu Jiying, 2014).

\section{B. Improvement Differences of Critical Thinking Sub-categories}

The second research question is to explore whether any improvement differences exist according to CT sub-categories. To determine the basis of difference, experimental subjects' CT scores on each sub-scale have been interpreted based on Paired Samples T-Test analysis and frequency analysis.

1. Critical Thinking Sub-dispositions

The characteristics of subjects' CTD are implied in the specific scaled scores. Therefore, the following table 7 presents the paired samples test of each sub-dispositions in experiment group.

TABLE VII.

PAIRED SAMPLES TEST OF EXPERIMENTAL ClASS's Ct SUB-DisPositions

\begin{tabular}{|c|c|c|c|c|c|c|c|}
\hline \multicolumn{4}{|c|}{ Paired Samples Statistics } & \multicolumn{4}{|c|}{ Paired Samples Test } \\
\hline \multirow[b]{2}{*}{ CT Sub-dispositions } & & \multirow[b]{2}{*}{ Mean } & \multirow[b]{2}{*}{$\mathrm{N}$} & \multicolumn{2}{|c|}{$\begin{array}{l}95 \% \text { Confidence Interval of the } \\
\text { Difference }\end{array}$} & \multirow[b]{2}{*}{$\mathrm{t}$} & \multirow[b]{2}{*}{ Sig. (2-tailed) } \\
\hline & & & & Lower & Upper & & \\
\hline \multirow[t]{2}{*}{ CT-confidence } & Pre_1 & 31.76 & 25 & \multirow{2}{*}{-3.907} & \multirow{2}{*}{1.507} & \multirow{2}{*}{-.915} & \multirow{2}{*}{.369} \\
\hline & Post_1 & 32.96 & 25 & & & & \\
\hline \multirow[t]{2}{*}{ Truth-seeking } & Pre_1 & 34.40 & 25 & \multirow{2}{*}{-5.283} & \multirow{2}{*}{.163} & \multirow{2}{*}{-1.941} & \multirow{2}{*}{.064} \\
\hline & Post_1 & 36.96 & 25 & & & & \\
\hline \multirow[t]{2}{*}{ Open-mindedness } & Pre_1 & 32.76 & 25 & \multirow{2}{*}{-3.233} & \multirow{2}{*}{.593} & \multirow{2}{*}{-1.424} & \multirow{2}{*}{.167} \\
\hline & Post_1 & 34.08 & 25 & & & & \\
\hline \multirow[t]{2}{*}{ Analiticity } & Pre_1 & 29.68 & 25 & \multirow{2}{*}{-7.378} & \multirow{2}{*}{-2.302} & \multirow{2}{*}{-3.936} & \multirow{2}{*}{.001} \\
\hline & Post_1 & 34.52 & 25 & & & & \\
\hline \multirow[t]{2}{*}{ Systematicity } & Pre_1 & 33.40 & 25 & \multirow{2}{*}{-3.386} & \multirow{2}{*}{1.706} & \multirow{2}{*}{-.681} & \multirow{2}{*}{.503} \\
\hline & Post_1 & 34.24 & 25 & & & & \\
\hline \multirow[t]{2}{*}{ Inqusitiveness } & Pre_1 & 31.92 & 25 & \multirow{2}{*}{-3.107} & \multirow{2}{*}{1.347} & \multirow{2}{*}{-.816} & \\
\hline & Post_1 & 32.80 & 25 & & & & .423 \\
\hline Maturity & Pre_1 & 35.12 & 25 & & & & \\
\hline & Post_1 & 35.96 & 25 & -3.116 & 1.436 & -.762 & .454 \\
\hline
\end{tabular}


Table 7 shows that the mean CTDI-CV score of each scale has moved on to a higher level. Notice that the P value of CT-confidence $(\mathrm{P}=0.369)$, Systematicity $(\mathrm{P}=0.503)$, Inquisitiveness $(\mathrm{P}=0.423)$ and Maturity $(\mathrm{P}=0.454)$ are all much higher than 0.05 , which indicates subjects' dispositions in these elements showed little changes. However, it is worth mentioning that the $\mathrm{P}$ value of Analyticity is $0.001(\mathrm{P}<0.05)$, proving that subjects' analyticity has reached the significant level.

After analyzing the paired sample test results, the frequency analysis of E-group's CT sub-dispositions in Figure 2 is presented as a supplement to examine the improvement differences.

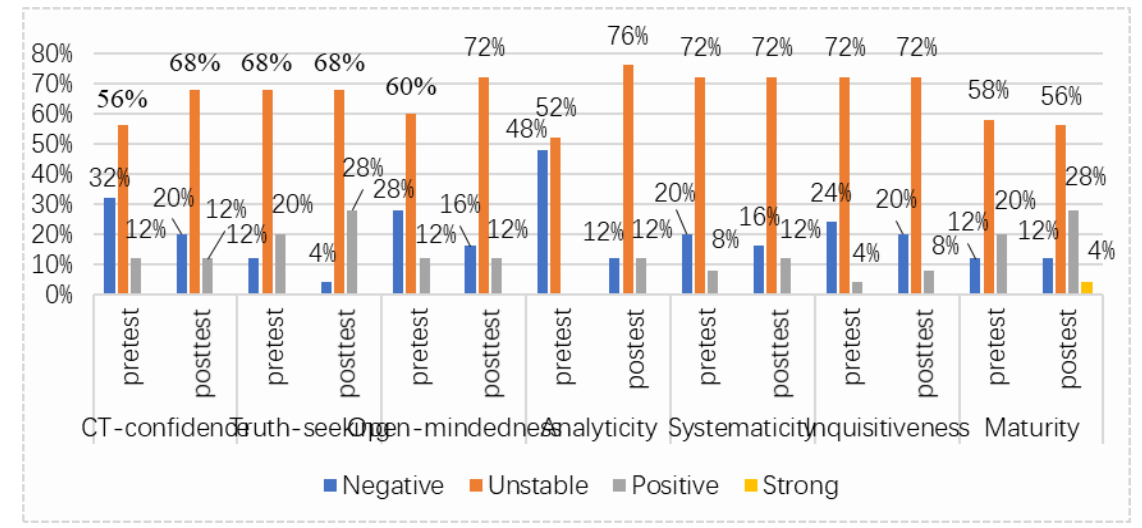

Figure 2. Frequency Analysis of E-Group'S Ct-Sub-Dispositions

As described in above figure 2, the number of subjects who show positive on truth-seeking, analyticity, systematicity, inquisitiveness and maturity scale is more or less on the increase. And for each sub-disposition, the number of students who show negative or unstable tendency toward CT is on the decrease. More specifically, for the analyticity scale, the percentage of students who score below 29 has decreased from $48 \%$ to $12 \%$, and meanwhile students who show positive dispositions on this scale have increased by $12 \%$. So, students' improvement inside the analyticity scale is more substantial than the others.

To sum up, the improvement differences of CT lies in the performance of CT sub-dispositions especially for the analyticity scale. The analyticity sub-scale measures the disposition to notice the potential problems and put forward effective solutions with reasons and evidences. It is believed that the significant difference in this element may be due to the emphasis in the task-based cooperative writing on developing learners' insight into given materials, encouraging learners to incorporate their thoughts and prior knowledge or experiences with these reading materials and communicating with peers to demonstrate their own ideas by applying reasons and using evidences.

2. Critical Thinking Sub-skills

Although the task-based cooperative writing provides significantly higher achievements for students' CTS integrally, the distributions and their related characteristics on each sub-scale can also mirror the development of students' CTS.

TABLE VIII.

PAIRED SAMPLES TEST OF EXPERIMENT Class’S CT-SUB-SKILLS

\begin{tabular}{|c|c|c|c|c|c|c|c|}
\hline \multicolumn{4}{|c|}{ Paired Samples Statistics } & \multicolumn{4}{|c|}{ Paired Samples Test } \\
\hline \multirow[b]{2}{*}{ CT Sub-skills } & & \multirow[b]{2}{*}{ Mean } & \multirow[b]{2}{*}{$\mathrm{N}$} & \multicolumn{2}{|c|}{$\begin{array}{l}\text { 95\% Confidence Interval of the } \\
\text { Difference }\end{array}$} & \multirow[b]{2}{*}{ t } & \multirow[b]{2}{*}{ Sig.(2-tailed) } \\
\hline & & & & Lower & Upper & & \\
\hline Interpretation & $\begin{array}{l}\text { Pre_1 } \\
\text { Post_1 }\end{array}$ & $\begin{array}{l}1.740 \\
3.380\end{array}$ & $\begin{array}{l}25 \\
25\end{array}$ & -2.019 & -1.261 & -8.925 & .000 \\
\hline Analysis & $\begin{array}{l}\text { Pre_1 } \\
\text { Post_1 }\end{array}$ & $\begin{array}{l}1.700 \\
3.100\end{array}$ & $\begin{array}{l}25 \\
25\end{array}$ & -1.884 & -.916 & -5.970 & .000 \\
\hline Evaluation & $\begin{array}{l}\text { Pre_1 } \\
\text { Post_1 }\end{array}$ & $\begin{array}{l}1.460 \\
3.020 \\
\end{array}$ & $\begin{array}{l}25 \\
25 \\
\end{array}$ & -2.019 & -1.101 & -7.016 & .000 \\
\hline Inference & $\begin{array}{l}\text { Pre_1 } \\
\text { Post_1 }\end{array}$ & $\begin{array}{l}1.420 \\
2.760\end{array}$ & $\begin{array}{l}25 \\
25\end{array}$ & -1.756 & -.924 & -6.650 & .000 \\
\hline Explanation & $\begin{array}{l}\text { Pre_1 } \\
\text { Post_1 }\end{array}$ & $\begin{array}{l}1.600 \\
2.780\end{array}$ & $\begin{array}{l}25 \\
25\end{array}$ & -1.617 & -.743 & -5.569 & .000 \\
\hline Self-evaluation & $\begin{array}{l}\text { Pre_1 } \\
\text { Post_1 }\end{array}$ & $\begin{array}{l}1.460 \\
1.580\end{array}$ & $\begin{array}{l}25 \\
25\end{array}$ & -.4981 & .2581 & -.655 & .519 \\
\hline
\end{tabular}

It can be seen that the mean value of each skill in pretest is around 2, indicating that a minimal level of using the CT skills is demonstrated in subjects' writing before the experiment. After intervention, the mean scores for CT sub-skills in pretest and posttest have more or less increased. And the $\mathrm{P}$ value for interpretation $(\mathrm{P}=0.000)$, analysis $(\mathrm{P}=0.000)$, explanation $(\mathrm{P}=0.000)$, inference $(\mathrm{P}=0.000)$ and evaluation $(\mathrm{P}=0.000)$ is all less than 0.05 . That is to say, students' performance on these CT sub-skills in prior writing has significantly differed from that in final writing. Nevertheless, it 
has been observed that the $\mathrm{P}$ value for self- regulation skill is $0.519(\mathrm{P}>0.05)$ and the mean value in pretest and posttest is respectively 1.46 and 1.58 .

After exploring the results of paired samples test, figure 3 presents the frequency analysis of experiment group's CT sub-skills to examine the improvement differences.

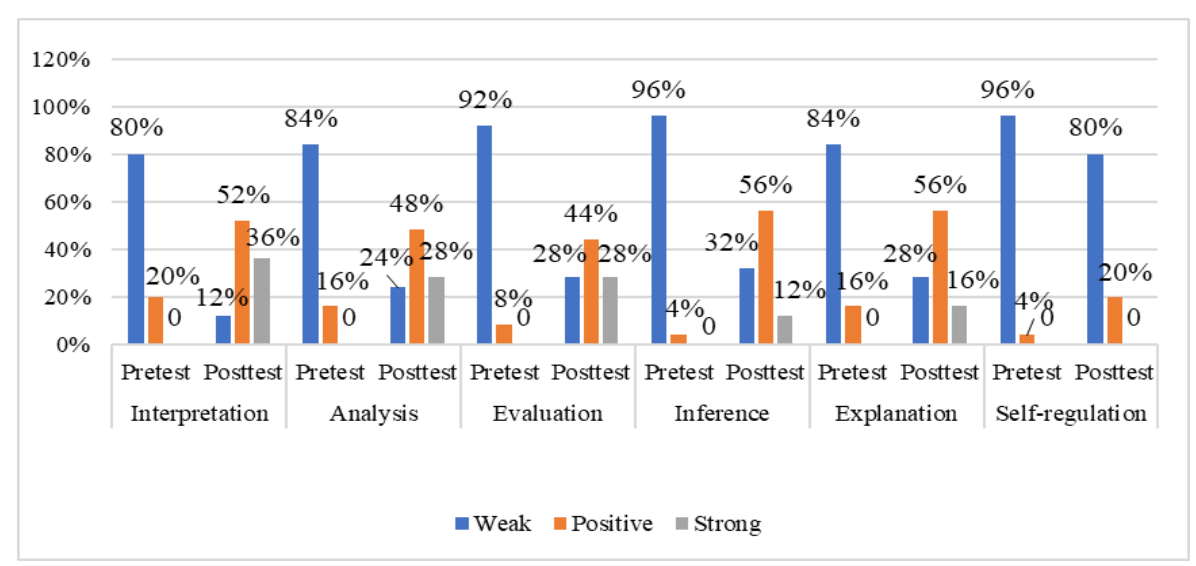

Figure 3. Frequency Analysis of E-Group'S Ct-Sub-Skills

When the frequency analysis is considered, students who show weakness in CT skills are sharply on decrease. The number of students, whose purpose of developing their CT skills in writing is achieved, has increased especially in the interpretation, analysis and evaluation, explanation and inference skills. And still no one after the experiment is thought to be strong in self-regulation skill. So, this skill is scarcely or rarely demonstrated in their writing, thus conforming the suggestions in other research (Tian Dan, 2012). On the one hand, 96\% students were rather weak in the self-regulation scale before the intervention of task-based cooperative writing and no one obtained the strong level before and after the experiment. The data trend illustrates students' self-regulation skill is depressing. On the other hand, although the task-based cooperative writing emphasized the evaluation of both students' logic and the linguistic features, students were not required to review and revise their writing after feedback. So, there is a gap between students' cognitive thinking and their actual writing. Tian (2012) mentioned that self-regulation may not be a concrete thinking method. Therefore, students' self-regulation is not easily demonstrated in their actual writing.

\section{Correlation between Writing Quality and Critical Thinking Ability}

After determining the effect of task-based cooperative writing and the improvement difference, the major focus of the current study has shifted to investigate whether students' writing quality could be improved along with the improvement of students' CT abilities and further the correlations between CT competency and writing quality.

1. Improvement of Writing Quality

Before discussing the associations between CT abilities and writing proficiency, it is significant to pin down participants' progress on writing quality. So, the independent samples test and paired samples test of two groups' writing scores are presented in following table 9 and table 10.

TABLE IX

INDEPENDENT SAMPLES TEST OF TWO CLASSES’ WRITING SCORES

\begin{tabular}{l|c|c|c|c|c|c|c|c|c}
\hline \multicolumn{9}{c}{ Group Statistics } & \multicolumn{4}{c}{ Independent Samples Test } \\
\hline & Class & N & Mean & Std. Deviation & Max & Min & F & t & Sig. (2-tailed) \\
\hline Pretest & 1 & 25 & 4.660 & 2.2160 & 9 & 2 & \multirow{2}{*}{.617} & -.305 & .762 \\
& 2 & 25 & 4.860 & 2.4132 & 10 & 2 & & -.305 & .762 \\
\hline Posttest & 1 & 25 & 8.740 & 3.0418 & 13 & 4 & \multirow{2}{*}{.148} & 3.537 & .001 \\
& 2 & 25 & 5.840 & 2.7489 & 11 & 3 & & 3.537 & .001 \\
\hline
\end{tabular}

It can be noticed that the $\mathrm{P}$ value in pretest is $0.762(\mathrm{p}>0.05)$, which reveals that subjects before attending different writing tasks do not achieve significantly different writing scores. And the mean scores for two classes are 4.86 and 4.66 respectively. Thus, the control group outperforms the experiment group in the writing proficiency at the beginning of the experiment. However, the $\mathrm{P}$ value in posttest is $0.001(\mathrm{P}<0.05)$, proving that two groups' writing quality significantly varies from each other after receiving the treatment. Likewise, the mean score of the experiment group has increased to 8.74. And the maximum in experiment class varies from 9 to 13 , while that in control class varies from 10 to 11 . To sum up, subjects' writing quality has been enhanced after implementing the task-based cooperative writing.

Additionally, the inner comparison of subjects' writing is performed based on the paired samples test to examine whether the significant improvement exists on their composition quality. 
TABLE X.

PAIRED SAMPLES TEST OF TWO CLASSES' WRITING SCORES

\begin{tabular}{|c|c|c|c|c|c|c|c|c|c|}
\hline \multicolumn{6}{|c|}{ Paired Samples Statistics } & \multicolumn{4}{|c|}{ Paired Samples Test } \\
\hline & & \multirow[b]{2}{*}{ Mean } & \multirow[b]{2}{*}{$\mathrm{N}$} & \multirow[b]{2}{*}{ Std. Deviation } & \multirow{2}{*}{$\begin{array}{c}\text { Std. Error } \\
\text { Mean }\end{array}$} & \multicolumn{2}{|c|}{$\begin{array}{c}95 \% \text { Confidence Interval } \\
\text { of the Difference }\end{array}$} & \multirow[b]{2}{*}{$\mathrm{t}$} & \multirow[b]{2}{*}{ Sig. (2-tailed) } \\
\hline & & & & & & Lower & Upper & & \\
\hline Class 2 & $\begin{array}{l}\text { Pre_2 } \\
\text { Post_2 }\end{array}$ & $\begin{array}{l}4.860 \\
5.840\end{array}$ & $\begin{array}{l}25 \\
25\end{array}$ & $\begin{array}{l}2.4132 \\
2.7489\end{array}$ & $\begin{array}{l}.4826 \\
.5498\end{array}$ & -2.4005 & .4405 & -1.424 & .167 \\
\hline Class 1 & $\begin{array}{l}\text { Pre_1 } \\
\text { Post_1 }\end{array}$ & $\begin{array}{l}4.660 \\
8.740\end{array}$ & $\begin{array}{l}25 \\
25\end{array}$ & $\begin{array}{l}2.2160 \\
3.0418\end{array}$ & $\begin{array}{l}.4432 \\
.6084\end{array}$ & -5.4819 & -2.6781 & -6.006 & .000 \\
\hline
\end{tabular}

Although the mean score in control class has increased from 4.86 to 5.84., the $\mathrm{P}$ value is .167 ( $\mathrm{P}>0.05)$, revealing that subjects' writing in pretest and posttest has not reached the significant level. The experiment group's mean of writing score has mounted from 4.66 to 8.74 . And the $\mathrm{P}$ value is .000 , which indicates that the experiment group's writing quality has been improved a lot after implementing the task-based cooperative writing instruction. Although both two groups make a progress in their writings, the results are more advantageous to conclude that the task-based cooperative writing instruction could also promote students' writing proficiency to a large extent.

2. Correlations Between Critical Thinking Dispositions and Writing Quality

On the basis of the former analysis, it can be noticed that both subjects' CT abilities and writing quality are both improved. So, is there any significant relationship between subjects' writing quality and their overall CT ability as well as the CT sub-dispositions and sub-skills?

In order to uncover the association, first, the Pearson correlation analysis between CTD in general and in categories and writing proficiency is all presented in the following table 11.

TABLE XI

CORRELATION ANALYSIS OF E-GROUP'S CTD AND WRITING QUALITY

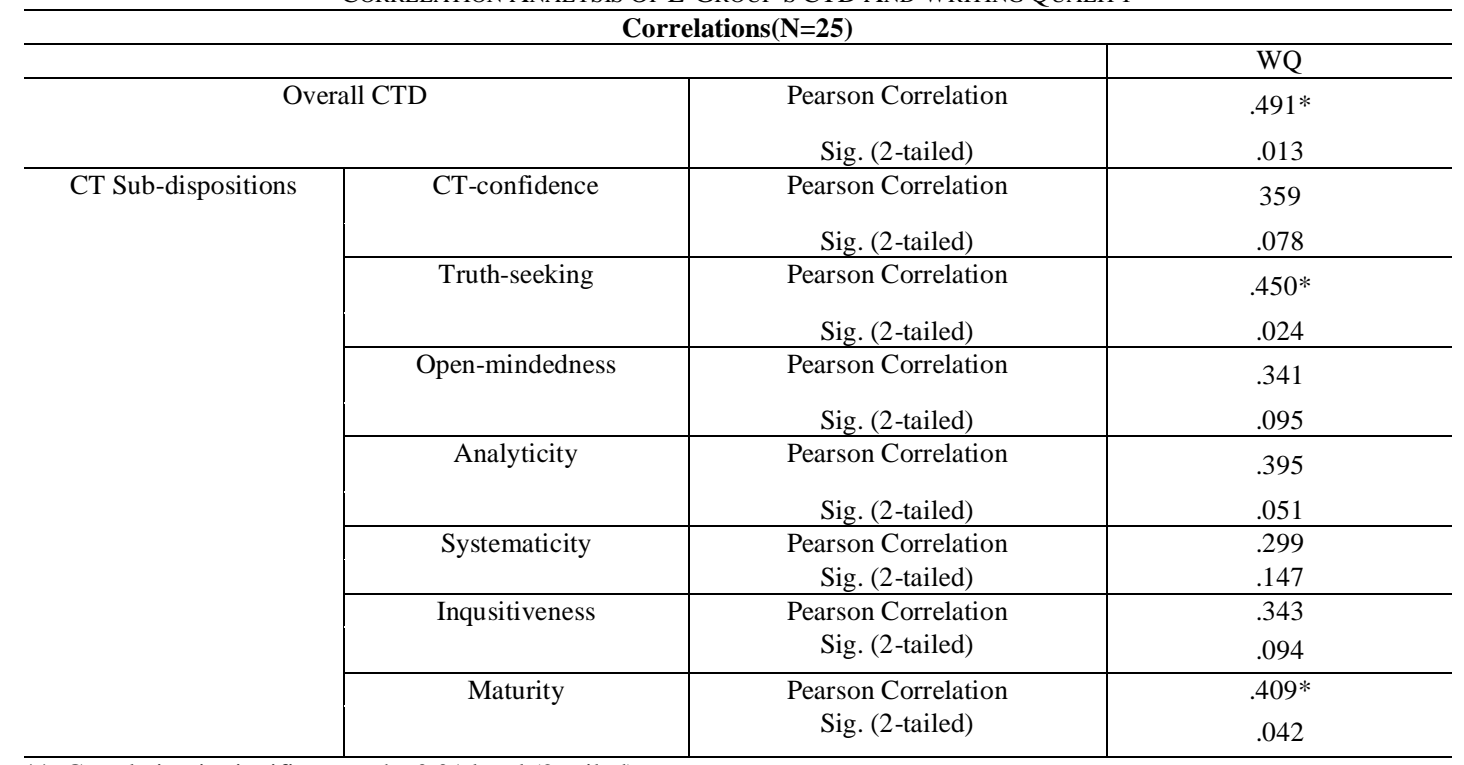

**. Correlation is significant at the 0.01 level (2-tailed).

*. Correlation is significant at the 0.05 level (2-tailed).

As demonstrated in above table, there is a positive correlation between students' holistic CTD and writing proficiency $(\mathrm{r}=0.491 ; \mathrm{P}=0.013<0.05)$. Meanwhile, it can be found that there is a positive correlation between writing proficiency and truth-seeking $(\mathrm{r}=0.450 ; \mathrm{P}=0.024<0.05)$ as well as maturity $(\mathrm{r}=0.409 ; \mathrm{P}=0.042<0.05)$. However, as for the CT-confidence, systematicity, analiticity, open-mindedness, and inquisitiveness, no significant correlation exists between them and writing proficiency.

3. Correlations Between Critical Thinking Skills and Writing Quality

This study mainly addresses to subjects' CTS in their writing. Below table 12 shows the Pearson Correlation Analysis of E-group's overall CTS and CT sub-categories and writing quality. 
TABLE XII.

CORRELATION ANALYSIS OF E-GROUP'S CTS AND WRITING QUALITY

\begin{tabular}{|c|c|c|c|}
\hline \multicolumn{4}{|c|}{ Correlations( $(\mathrm{N}=25)$} \\
\hline & & & WQ \\
\hline \multirow{2}{*}{\multicolumn{2}{|c|}{ Overall CTS }} & Pearson Correlation & $.969 * *$ \\
\hline & & Sig. (2-tailed) & .000 \\
\hline \multirow[t]{6}{*}{ CT Sub-skills } & Interpretation & $\begin{array}{l}\text { Pearson Correlation } \\
\text { Sig. (2-tailed) }\end{array}$ & $\begin{array}{c}867 * * \\
.000\end{array}$ \\
\hline & Analysis & $\begin{array}{l}\text { Pearson Correlation } \\
\text { Sig. (2-tailed) }\end{array}$ & $\begin{array}{c}.918^{* * *} \\
.000\end{array}$ \\
\hline & Evaluation & $\begin{array}{l}\text { Pearson Correlation } \\
\text { Sig. (2-tailed) }\end{array}$ & $\begin{array}{l}.941 * * \\
.000\end{array}$ \\
\hline & Inference & $\begin{array}{l}\text { Pearson Correlation } \\
\text { Sig. (2-tailed) }\end{array}$ & $\begin{array}{c}.853 * * \\
.000\end{array}$ \\
\hline & Explanation & $\begin{array}{c}\text { Pearson Correlation } \\
\text { Sig. (2-tailed) } \\
\end{array}$ & $\begin{array}{c}.875^{* *} \\
.000 \\
\end{array}$ \\
\hline & Self-regulation & $\begin{array}{l}\text { Pearson Correlation } \\
\text { Sig. (2-tailed) }\end{array}$ & $\begin{array}{l}.482^{*} \\
.015\end{array}$ \\
\hline
\end{tabular}

The results indicate that the writing quality is significantly correlated with the holistic CTS $(r=0.969 ; \mathrm{P}=0<0.01)$. As for the correspondent $\mathrm{CT}$ sub-skills, results indicate that writing quality has significant associations with evaluation $(\mathrm{r}=0.941 ; \mathrm{P}=0.000<0.01)$, analysis $(\mathrm{r}=0.918 ; \mathrm{P}=0=0.000<0.01)$, explanation $(\mathrm{r}=0.875 ; \mathrm{P}=0.000<0.01)$, interpretation $(\mathrm{r}=0.867 ; \mathrm{P}=0.000<0.01)$, inference $(\mathrm{r}=0.853 ; \mathrm{P}=0.000<0.01)$ and a positive correlation with self-regulation $(\mathrm{r}=0.482$; $\mathrm{P}=0.015<0.05)$.

\section{CONCLUSION}

Based on the results and discussion above, some major findings concerning the three research questions can be obtained, and some pedagogical implications can be suggested.

\section{A. Major Findings}

First of all, students' CT dispositions and CT skills have been both improved to a significant extent after a few week's intervention on writing instruction, through implementing the task-based cooperative writing.

Secondly, as for CT sub-dispositions and sub-skills, the affective analiticity dimension is improved most, while for CT sub-skills, all the sub-skills except the self-regulation scale are enhanced significantly.

Moreover, on the relationship between students' writing quality and CT abilities, there is a positive correlation between each other. As for the correlations between CT sub-categories and writing quality, the CT sub-dispositions of 2 scales ("truth-seeking" and "maturity") are positively correlated with students' writing and the CT sub-skills all have positive or strong associations with writing proficiency.

\section{B. Pedagogical Implications}

Firstly, college English teachers should recognize the necessity of implementing the CT in their teaching from more consultation and training. It can be discovered that college English teaching in the Chinese context seems to be the severe target for lack of cultivation of CT based on the literature review. Thus, college English practitioners' perception of embedding CT in the writing teaching can be considered as a powerful motivator for improving students' CT and writing quality.

Secondly, the writing teaching should emphasize the importance of task-based writing approach and various writing tasks and interaction patterns could be designed to stimulate students' CT awareness and application.

Meanwhile, college English students should strengthen their perceptions of being an active thinker and autonomous learner, and learn to focus on their writing process and evaluate, monitor and pinpoint their weaknesses on CT especially for inference, explanation and self-regulation skills.

\section{REFERENCES}

[1] Appel, G., \& Lantolf, J. P. (1994). Speaking as mediation: A study of L1 and L2 text recall tasks. The modern language journal, $78(4), 437-452$.

[2] Cliff Hodges, G. (2002). Learning through collaborative writing. Reading, 36(1), 4-10.

[3] Delaney, Y. A. (2008). Investigating the reading-to-write construct. Journal of English for academic purposes, 7(3), 140-150.

[4] Dewey, J. (1933). How We Think: A Restatement of the Relation of Reflective Thinking to the Educative Process Vol. 8. Boston, MA: D. C. Health and Company.

[5] Ellis, R. (2003). Task-based language learning and teaching. Oxford: Oxford University Press.

[6] Ennis, R. H., Millman, J., \& Tomko, T. N. (1985). Cornell critical thinking tests level X \& level Z: Manual. Pacific Grove, CA: 
Midwest Publications.

[7] Facione, P.A. \& N.C. Facione. (1992). Holistic Critical Thinking Scoring Rubric. Millbrae: The California Academic Press.

[8] Facione, P.A. (1990). Critical thinking: A statement of expert consensus for purposes of educational assessment and instruction (The Delphi Report). Millbrae, CA: The California Academic Press.

[9] Fisher, A. (2011). Critical thinking: An introduction. Cambridge: Cambridge University Press.

[10] Han Shaojie et al. (2009). English Writing Teaching and Cultivation of Critical Thinking Ability. Foreign Language and Literature Studies, 26(1), 24-28.

[11] Karami, M., Pakmehr, H., \& Aghili, A. (2012, February). Another view to importance of teaching methods in curriculum: collaborative learning and students' critical thinking disposition. In 4th World Conference on Educational Sciences.

[12] Li Wenting. (2012). The Teaching of English Writing and the Cultivation of Students' Thinking Ability. Foreign Language and Literature (s1), 155-156.

[13] Lin Yan. (2014). Impact of the intensive reading-and-writing practice on the development of critical thinking skills in English content courses. Foreign Language World (5), 11-19.

[14] Lowry, P. B., Curtis, A., \& Lowry, M. R. (2004). Building a taxonomy and nomenclature of collaborative writing to improve interdisciplinary research and practice. The Journal of Business Communication (1973), 41(1), 66-99.

[15] Ma Rong \& Qing Xiaoqing. (2016). Research on the characteristics of critical thinking disposition of English majors. Journal of Xi' an International Studies University, 24(4), 60-63.

[16] Peng Meici, Wang guocheng, Chen Jile, Chen Manhui, Bai Honoghai, \& Li. (2004). Study on the reliability and validity of critical thinking ability measurement scales. Chinese Journal of Nursing, 39(9), 644-647.

[17] Sun Zhongyou. (2011). Discussion on English WritingTeaching and Critical Thinking Cultivation of English Majors. Foreign Language Teaching Research, (4), 603-608.

[18] Tian Dan. (2012). Typology of EFL writing tasks and the cultivation of college students' critical thinking. Beijing: Economic Science Press.

[19] Tsui, L. (1999). Courses and instruction affecting critical thinking. Research in Higher Education, 40(2), 185-200.

[20] Wang Dongping. (2005). An Empirical Study on Task-based College English Writing Teaching. Journal of Nanjing University of Aeronautics and Astronautics, 7(2), 79-83.

[21] Wang Qiyun, Woo, Huaylit., \& Zhao Jianhua. (2009). Investigating critical thinking and knowledge construction in an interactive learning environment. Interactive learning environments, 17(1), 95-104.

[22] Wang Wenqiu, \& Mou Fanghua. (2013). Concept and Practice of "Reading and Writing Integration" Course Design. Foreign Language and Literature, (s1), 170-173.

[23] Watson, G. (1980). Watson-Glaser critical thinking appraisal. San Antonio, TX: Psychological Corporation.

[24] Wen Qiufang \&Zhou Yan. (2006). A Review on the Development of the Critical Thinking Ability of Foreign Language Major Students. Foreign Language Research, (5), 76-80.

[25] Willis, J. (1996). A flexible framework for task-based learning. TESOL Quarterly, 33, 157-158

[26] Xu Hao, \& Gao Caifeng. (2007). An Empirical Study on Junior Engliah Major students' Reading and Writing Integration Approach. Modern Foreign Languages, 30(2), 184-190.

[27] Xu Jiajin, \& Jia Yunlong. (2009). Readability Analyzer 1.0: A text difficulty analyzing tool. Beijing: The National Research Centre for Foreign Language Education, Beijing Foreign Studies University.

[28] Yu Jiying. (2014). An integrated teaching approach to English writing and critical thinking skills development. Foreign Language World, (5), 20-28.

[29] Zhang Xinling. (2009). An Interface between Critical thinking and reading-to-writing instruction. Journal of Beijing International Studies University, 31(10), 73-78.

[30] Zhang Xinling, \& Zhou Yan. (2016). Impact of Different Tasks on the Writing Process of Chinese EFL Learners with Higher and Lower language proficiency. Journal of PLA University of Foreign Languages, 39(1), 87-95.

Xiaoling Liu was born in Ningxiang, Hunan, P.R. China in 1964. She received her TESOL certificate from City University of New York and master's degree from Hunan University, P.R. China in 1987. She is currently a full professor in the College of Foreign languages, Hunan University, Changsha, Hunan, P.R. China. Her research interests include Applied Linguistics, Foreign language Teaching and Learning.

Ting Yao was born in 1992. She received her master's degree from Hunan University in 2017. She is currently teaching in the third middle school in You County, Zhuzhou, Hunan, P.R. China. Her research interest is Foreign language Teaching and Learning. 